IJ§ER

ISSN: $2149-5939$
International Journal of Social Sciences and Education Research

Online, http://dergipark.gov.tr/ijsser

Volume: 3(3), 2017

\title{
Bankacılık sektöründe insan kaynakları yönetimi açısından yetenek yönetimi üzerine bir araştırma
}

\section{A research on talent management in terms of human resources management in the banking sector}

Pınar Göktaş ${ }^{1}$

\author{
Koray Çetinceli2
}

\begin{abstract}
Received Date: $01 / 01 / 2017$
$\ddot{O} z$

Accepted Date: $13 / 03$ / 2017

Günümüzde küreselleşmenin etkisiyle artan uluslararası rekabet ve teknolojik alanda meydana gelen gelişmeler işletmeler açısından değişimin gerekliliğini beraberinde getirmektedir. Değişimin en fazla hissedildiği alanlardan biri de insan kaynakları yönetimidir. Işletmelerin çağın gereksinimlerini karşılayacak, potansiyeli yüksek, yetenekli çalışanlara olan ihtiyacı giderek artmaktadır. Bu ihtiyaçlar neticesinde ortaya çıkan yeni kavramlardan biri de "Yetenek Yönetimi”dir. Yetenek yönetimi kavramı, organizasyonların küresel işgücünü bünyelerine çekmesi, elde edilen iş gücünün mevcut durumunu koruması ve yönetilmesi konularında işletme stratejileri arasında yeni bir vizyon olarak karşımıza çıkmaktadır. Bu bağlamda en yetenekli çalışanları biraraya getirmeyi hedefleyen hizmet yoğun sektörlerden bir tanesi de bankacılık sektörüdür. Bankacılık sektörü insan kaynağına yatırım yaparak bu hedefini gerçekleştirmekte ve bunun sonucunda maksimum karlılık ve verimliliğe ulaşılması beklenmektedir. Bu çalışmanın amacı yetenek yönetimi uygulamalarının insan kaynă̆ lamda Türk bankacılık sektöründe lider konumunda olan 3 bankanın insan kaynaklarl yetenek yönetim birimlerindeki uzmanlar ile görüşme yöntemi aracılı̆̆ıla veri toplanmıştır. Toplanan veriler değerlendirilerek Türk Bankacılık sektöründe yetenek yönetimi ile ilgili görüşler ortaya konulmuştur. Araştırmadan elde edilen bulgular ışı̆̆ında etkin yetenek yönetimi uygulamalarının bankacılı sektöründe faaliyet gösteren finans kuruluşlarının varlıklarını sürdürebilmeleri için kritik öneme sahip insan kaynă̆ı üzerinde önemli bir etkiye sahip olduğu görülmüştür.
\end{abstract}

Anahtar sözcükler: Bankacılık sektörü, insan kaynaklarl yönetimi, yetenek yönetimi, yetenek yönetimi uygulamaları, insan kaynakları

\begin{abstract}
Today, increased international competition and technological developments with the impact of globalization brings about the necessity of change in terms of businesses. One of area where change is most felt is human resource management. The need for high potential and skilled workers is increasing to meet the requirements of the era of the business. One of the new concepts resulting from these needs is "Talent Management". The concept of talent management is encountered as a new vision between business strategies to incorporate global workforce of the organization, to protect in the current situation of workforce and to management. In this context, one of the serviceintensive industry which aims to bring together the most talented employees is the banking sector. The banking sector by investing in human resources to achieve this target and is expected to reach maximum profitability and efficiency as a result of it. This study aims to reveal the impact on human resources of talent management practices. In this context, data were collected through intervievs with human resources experts in talent management unit who working in 3 bank that leading position in Turkish banking sector. Opinions about the talent management in the Turkish banking sector has been determined by evaluating data. The findings obtained from this study showed that effective talent management practices have a significant impact on the human resources who have critical importance to maintain existence of financial institutions that operating in the banking sector.
\end{abstract}

Keywords: Banking sector, human resources management, talent management, talent management practices, human resources

${ }^{1}$ Yrd. Doç. Dr., Süleyman Demirel Üniversitesi, İktisadi ve İdari Bilimler Fakültesi, İnsan Kaynakları Yönetimi Bölümü, pinargoktas@sdu.edu.tr

${ }^{2}$ Öğr. Gör., Süleyman Demirel Üniversitesi, Isparta Meslek Yüksekokulu, Finans Bankacılık ve Sigortacılık Bölümü, koraycetinceli@sdu.edu.tr 
Göktaş, P., Çetinceli, P. (2017). A research on talent management in terms of human resources management in the banking sector. International Journal of Social Sciences and Education Research, 3(3), 720-733.

\section{Giriş}

Küreselleşme ile birlikte hızlı değisim ve belirsizliğin hâkim olduğu iş ortamında işletmeler hedeflerine ulaşabilmek için çalısanlarının sahip oldukları birbirinden farklı yeteneklerinin ortaya çıarılmasına önem vermektedir. Bu hususta işletmeler bu niteliklere sahip işgörenleri istihdam etmek ve onları doğru yerde, doğru şekilde değerlendirerek potansiyellerinden en üst düzeyde faydalanabilmeyi arzu etmektedir. Böylece sahip oldukları ayırt edici özellikleriyle bu işgörenler, işletmeyi rakipleri karşısında avantajlı konuma geçirebileceklerdir (Selznick, 1984:42). Dolayısıyla işletmelerin çağın gereksinimlerini karşılayacak, potansiyeli yüksek, yetenekli çalışanlara olan ihtiyacı giderek artması neticesinde "Yetenek Yönetimi" önem arz etmektedir. Yetenek yönetimi uygulamalarının gerçekleştiği sektörlerden biri bankacılık sektörüdür. Özellikle 1980’li yıllarda yabancı bankaların Türkiye'de hizmet vermeye başlamasıyla bankacılık sektöründe yoğun rekabet ortamı oluşmuş ve sektör çok önemli dönemlerden geçmiştir. Bu bağlamda bankalar yeni pazarlama stratejileri geliştirmeye, daha geniş kitlelere hizmet vermeye ve etkin yetenek yönetimi uygulamalarına yönelmiştir (Timur, 2006: 9). Böylece bankacılık sektöründe yetenek yönetimi uygulamalarına önem verilerek karşılaşacakları zorluklarla baş edebilmeleri ve stratejilerini hayata geçirerek hedeflerine ulaşabilmeleri mümkün olabilmekte ve bununla beraber ihtiyacı olan yetenekler ile sahip olduğu mevcut yetenekleri arasındaki boşluk giderek kapanabilmektedir.

Türkiye'de bankacılık sektöründeki insan kaynakları yönetimi açısından yetenek yönetimi faaliyetleri hakkında bir durum değerlendirmesi yapmak üzere hazırlanan bu çalışmada yetenek yönetimi uygulamalarının insan kaynağı üzerindeki etkisini ortaya koymak amaçlanmaktadır. Bu bağlamda Türk bankacılık sektöründe lider konumunda olan 3 bankanın insan kaynakları yetenek yönetim birimlerindeki uzmanlar ile görüşme yöntemi aracılığıyla veri toplanmıştır. Toplanan veriler değerlendirilerek Türk Bankacılık sektöründe yetenek yönetimi ile ilgili görüşler ortaya konulmuştur. Araştırmadan elde edilen bulgulara göre bankacılık sektöründe yetenek yönetimi uygulamasıyla çalışanların kariyer imkânlarının düzenlenmesi doğru işin doğru personel tarafından yapılması ve bu sayede müşteri odaklı hizmetin sürdürülebilir rekabet üstünlüğü sağlanmas1nın mümkün olabileceği görüşü belirtilmiştir.

\section{Yetenek yönetimi kavramı ve gelişim süreci}

"Yetenek, kişinin belirli ilişkileri kavrayabilme, analiz edebilme, çözümleyebilme, sonuca varabilme gibi zihinsel özellikleri ve bazı olguları gerçekleştirebilmesi şeklindeki bedensel özelliklerinin tamamıdır. Bu durumda yetenek, bireylerin davranışlarını düzenlemede yararlandıkları zihinsel ve bedensel kapasiteleri olarak düşünülebilir” (Erdoğan, 1999: 87). Özellikle günümüzde rekabetçi iş dünyasında rakiplere karşı üstünlük sağlayabilmenin yolunun müşterilere farklı ya da benzersiz ürün ve hizmet sunabilmek olduğu, bunu sağlayabilecek varlığın ise, nitelikli işgörenlerin sahip oldukları yeteneklerinin işletme süreçlerinin her kademesinde doğru şekilde değerlendirilmesi hususunda görüş birliği oluşmaya başlamıştır. Bu sebeple işletmeler açısından "insanların yönetimi” yerine "yeteneklerin yönetimi” önem kazanmaya başlamıştır (Alayoğlu, 2010: 74-75).

Literatürde yetenek yönetimine ilişkin birçok tanım yer almakla birlikte tutarlı ve basit tek bir tanımı bulunmamaktadır (Ashton ve Morton, 2005: 30). Bu tanımlardan bazıları şunlardır:

"Yetenek yönetimi, işletmenin gereksinimleri doğrultusunda doğru işgörenlerin doğru zamanda doğru işlerde ve doğru uygulamaları yapabilmelerinin sağlanmasıdır" (Mucha, 2004:99). 
Göktaş, P., Çetinceli, K. (2017). Bankacılık sektöründe insan kaynakları yönetimi açısından yetenek yönetimi üzerine bir araştırma. International Journal of Social Sciences and Education Research, 3(2), 720-733.

"Yetenek yönetimi bir konular kümesi olmayıp, bir perspektif veya anlayıştır" (Creelman, 2004: 3).

"Yetenek yönetimi, bir işletmenin tüm kademelerinde yer alan yöneticiler arasında işbirliği ve iletişimi gerektiren; işgücü planlaması, personel alımı, eğitilmesi, geliştirilmesi, yeteneklerin gözden geçirilmesi, yedekleme planlaması, performans değerlendirme, yeteneklerin elde tutulması gibi çeşitli aşamaları içeren ve günümüzde birçok işletmenin zorunlu olarak karşı karşıya kaldığı yeni bir yaklaşım olarak ele alınmaktadır" (McCauley ve Wakefield, 2006: 4).

Tanımlardan da anlaşılacağı üzere yetenek yönetimi kapsamlı ve entegre bir süreçtir. Ayrıca genel işletme stratejisi ile uyumlaştırılması ve üst düzey yönetimin yetenek yönetimi bakış açısına sahip olması gerekmektedir. Yetenek yönetimi stratejisi belirlenirken işletmenin vizyon, misyon, amaçları, insan kaynağı potansiyeli ve ihtiyacı göz önünde bulundurulmalıdır.

Yetenek yönetimi tek bir uygulama yerine birden çok uygulamayı kapsayan bir süreç olup bu süreçte; üstün yetenekler için kariyer yollarının ve ödüllendirme programlarının tanımlanması, oluşturulması ve geliştirilmesi; işletmenin kilit pozisyonlarının ve yedekleme sistemlerinin tanımlanması; her bir yatırım kategorisinde yetenek havuzlarının "üstün yetenekli, güvenilir çalışan ve uyumsuz çalışan" olarak sınıflandırılması ve her kategoride bu sınıfların uygun şekilde yönetilmesi gerekmektedir (Berger, 2004). Bu bağlamda yetenek yönetimi günümüzde stratejik bir olgu olarak değerlendirilmelidir. İş gücü planlaması, yetenek çatışma analizi, işe alma süreci, eğitim ve geliştirme faaliyetleri, elde tutma faaliyetleri, yetenek özetleri ve yedekleme planları yetenek yönetimi sürecinde yer almaktadır (McCauley ve Wakefield, 2006: 4). Bunlara ilave olarak yetenek yönetimi ile kurumda işe alınacak, işe alınanı elde tutacak ve yetenek havuzunu oluşturacak özel stratejiler geliştirilmektedir (Doğan ve Demiral, 2008:150).

Günümüz şartlarında performansın yönetilmesi oldukça hızlı bir süreç olup firmalar stratejilerini hayata geçirebilmek için bu hızlı değişimle karşı karşıya kalmaktadırlar. Bu bağlamda rekabetin yoğun olduğu bir dünyada firmalar ayakta kalabilmek için en iyi performansı alabilecekleri doğru kişileri doğru yerde istihdam etmeleri gerekmektedir. Dolayısıyla yetenek yönetimi ile örgütlere rekabet avantajı sağlayabilmek ve örgütün stratejik hedeflerini gerçekleştirme doğrultusunda ihtiyaç duyduğu yüksek performans ve potansiyele sahip kişilerin örgüte kazandırılması, gelişim imkanlarının sunulması ve elde tutulmasını sağlamak mümkün olabilecek; tasarlanmış yöntem, süreçler, kaynaklar ve politikaları kullanarak örgüt içinde yer alan yüksek yetenek sahibi bireylere kariyer geliştirme ve ilerletme imkanları sunulabilecektir. Yetenek yönetimi süreci kapsamında sunulan bu imkanlar dahilinde örgütün geleceği için işgören ve liderlerin geliştirilmesine odaklanılmakta ve arzu edilen yeteneğe sahip insanların örgüte dahil edilmesi için rekabetçi bir temelde uygulamalar yürütülmektedir. Bu bağlamda örgütler yetenek yönetimini sağlayabilmek için rekabetçi ücret politikaları sağlamakta, yeteneği açığa çıkaracak eğitim ve gelişim firsatları sunmakta, performans yönetimi süreçlerini uygulamakta, elde tutma faaliyetlerini gerçekleştirmekte, iş görenlerin yatay ve dikey kariyer hareketliliğini yönetmekte ve yaşam boyu öğrenmeyi desteklemektedir (Tabancalı ve Korumaz, 2014: 143).

\subsection{Yetenek yönetimi açısından işe alım süreci ve performans değerlendirme}

Örgütün geleceği için çalışanların ve liderlerin geliştirilmesine odaklanılan yetenek yönetim sürecinde arzu edilen yeteneğe sahip bireylerin örgüte dahil edilmesi hususunda rekabetçi bir temelde yürütülen uygulamalar bulunmaktadır. Bu hususta örgütler yetenek yönetimini sağlayabilmek için rekabetçi ücret politikaları sağlamakta, yeteneği keşfedecek eğitim ve gelişim olanakları 
Göktaş, P., Çetinceli, P. (2017). A research on talent management in terms of human resources management in the banking sector. International Journal of Social Sciences and Education Research, 3(3), 720-733.

sunmakta, performans yönetimi süreçlerini uygulamakta, elde tutma faaliyetlerini gerçekleştirmekte, iş görenlerin yatay ve dikey kariyer hareketliliğini yönetmekte ve yaşam boyu öğrenmeyi teşvik etmektedir (Atl1, 2012). Yetenek yönetimi sürecinde dikkat edilmesi gereken en önemli husus yetenekli personelin tespit edilmesidir. Bu bağlamda yetenek yönetimi stratejileri oluşturulurken işletmenin vizyon, misyon, amaçları, insan kaynağı potansiyeli ve gereksinimleri göz önünde bulundurulmalıdır. Örgüt içerisinde terfi edebilme durumu olabilecek çalışanların doğru bir şekilde tahmin edilmesi ne kadar önemli ise doğru yeteneklere ne zaman ve nerelerde ihtiyaç duyulduğu da aynı şekilde önem taşımaktadır (Keçecioğlu, 2012: 182). İşletmenin gereksinim duyduğu personelin tespit edilmesi ve işe alım süreci geleceğe dair planlama yapılmasında büyük bir yere sahiptir. İşe alım sürecinde, personel alımı yapılacak olan görevin gerektirdiği özelliklere uygun nitelikler ve yetenekleri olan adayların seçilmesi amaçlanmaktadır. Başka bir deyişle, işe alım sürecinde iş ile iş gören arasında bir uyum olmasına dikkat edilmelidir. Bu doğrultuda ilk olarak yapılması gereken husus, işin gerektirdiği özellik ve yeteneklerin neler olduğuna karar verilmesidir. (Bingö1, 2013: 229). Sonrasında yetenekli personelin işe alım süreci hiyerarşik kodlama, işe alım ve işten çıkarım kuralları, ücretlendirme gibi konuları da kapsamakla beraber çalışanların özellikleri, işçi arz ve talebi arasında eş zamanlı karşılaştırma yapma imkanı sunulmaktadır (Levis ve Heckman, 2006: 140). Böylece yetenekli bireylerin keşfedilerek işletmeye çekilmesi ve doğru yerlerde görevlendirilmesi mümkün olabilmektedir.

İşletmeler açısından yetenek yönetimi bağlamında hayati bir öneme sahip olan performans yönetimi uygulamaları sayesinde çalışanların yeteneklerinin tanınması mümkün olabilmektedir. $\mathrm{Bu}$ bağlamda bireysel performans, beklenen hedeflere ulaşmak için işgörenin yetenek ve motivasyonuyla ortaya koyduğu davranış ve sonuçları ifade etmekte iken örgütsel performans ise kar, gelirler gibi finansal sonuçları, satışlar, pazar payı, tüketici memnuniyeti gibi pazar sonuçlarını, verimlilik, kalite ve etkinlik gibi yönetim sonuçlarını ele almaktadır (Uysal, 2015: 33). Performans değerlendirmede ise çalışanın yeteneklerinin işin nitelik ve gereklerini ne ölçüde karşıladığg 1 araştırılmaktadır (Sabuncuoğlu ve Tokol, 2013). Dolayısıyla hem performans yönetimi hem de performans değerlendirmesi açısından yetenek yönetimi önem arz etmektedir.

\subsection{Yetenek yönetimi açısından eğitim ve ücret yönetimi}

İşgören seçiminde seçme ve yerleştirme tekniklerinden hangisi kullanılırsa kullanılsın, işgörenin bilgi ve yeteneklerinin yüzde yüz işe uyumunun sağlanması, başka bir deyişle uygun işe uygun personel seçiminin tam olarak gerçekleştirilmesi insan kaynakları yöneticileri açısından oldukça güçtür. Bu güçlük, seçim tekniğinin yetersizliği yerine insanları doğru tanımanın ve özelliklerini tespit edebilmenin zorluğundan kaynaklanmaktadır. Bunu gidermenin en iyi yolu eğitimdir (Uyargil ve diğerleri, 2010, 162). Bu bağlamda işletmelerde uygulanan eğitim ve geliştirme işlevi, çalışanların sorun çözme, karar verme, yeni durumlara uyum sağlama, işletme politikalarını anlama ve kavrama yeteneklerinin geliştirilmesi ile ilgili çalışmalardan oluşmaktadır (Aldemir, Ataol ve Budak, 2004: 167). Bununla beraber çalışanların mevcut görevlerinde kalabilmeleri veya başka bir işyerinde yeni bir iş bulabilmeleri hususunda eğitim ve geliştirme programları ile onların yeni yetenek ile becerilere sahip olmaları mümkün olabilmektedir (Muradova, 2007: 80). Dolayısıyla eğitim ve geliştirme işlevi yetenek yönetimi bağlamında çalışanların yeteneklerinin geliştirilmesi hususunda önem taşımaktadır.

İşgörenlerin yeteneklerini işletmede tam olarak kullabilmesi için işgörenlerin örgüte ve örgütün hedeflerine, değerlerine ve stratejilerine bağl1lıklarını artıracak şekilde onları yetkilendirme, 
Göktaş, P., Çetinceli, K. (2017). Bankacılık sektöründe insan kaynakları yönetimi açısından yetenek yönetimi üzerine bir araştırma. International Journal of Social Sciences and Education Research, 3(2), 720-733.

özendirici ücret gibi destekleyici ve tutarlı insan kaynă̆ uygulamalarını gerçekleştirmek gerekmektedir (Beer ve Cannon, 2004; Purcell, 2001:59). Bu hususta yetenekli işgörenlerin cezbedilmesi ve organizasyona katılımlarının sağlanması açısından ücret ve ödüllendirme sistemleri işletmeyi rakiplerine nazaran farklı ve cazip kılacak uygulamalar arasında yer almaktadır (Alayoğlu, 2010: 81). Dolayısıyla eğitim ve ücretlendirme gibi insan kaynakları fonksiyonları yetenek yönetimi uygulamalarıyla entegre olarak yürütülmesi gerekmektedir (Çırpan ve Şen, 2009: 113).

\section{Araştırma metodolojisi}

\subsection{Araştırmanın amact ve önemi}

Hizmet yoğun sektörlerden biri olan bankacıllk sektöründe çalışan bireylerin yetenekleri oldukça önemlidir. Dolayısıyla çalışma performansı açısından standart bir çalışanın önüne geçen yetenekli çalışanların istihdam edilmesi ve devamlılığı sağlanarak işletmede yüksek düzeyde karlılık ve verimlilik hedeflenmektedir. Bu hedefe ulaşabilmek için bankacılık sektöründe çeşitli yetenek yönetimi uygulamalarına yer verilmektedir.

$\mathrm{Bu}$ çalışmanın amacı yetenek yönetimi uygulamalarının, bankacılık sektöründe faaliyet gösteren finans kuruluşlarının varlığını sürdürebilmesindeki en önemli faktörlerden olan insan kaynağ 1 üzerindeki etkisini ortaya koymaktır. Bu bağlamda Türk bankacılık sektöründe lider konumunda olan 3 bankanın insan kaynakları yetenek yönetim birimlerindeki uzmanlar ile görüşme yöntemi aracılığıyla yetenek yönetimi konusundaki uygulamaları incelenmiş olup bu açıdan çalışma önem arz etmektedir.

\subsection{Araştırmanın kapsamı ve yöntemi}

Araştırmanın evreni 2016 yılında faaliyette bulunan Türk Bankacılık sektörüdür. Bu kapsamda 2016 yılında faaliyet gösteren Türk bankacılık sektöründe lider konumunda olan üç devlet bankası seçilmiştir. Üç bankanın toplam beş insan kaynakları yönetimi yetenek yönetimi uzmanının görüşü ile araştırma sınırlandırılmıştır. Görüşme yapılan uzmanların üçü kadın olup ikisi erkektir. Uzmanlardan biri 5 yıldan az deneyime sahip iken, diğer uzmanlar ise 6-10 yıl arasında çalıştığını beyan etmiştir.

Araştırma yöntemi olarak nitel araştırma tekniği tercih edilmiştir. Bu bağlamda insan kaynakları yetenek yönetim birimlerindeki uzmanlara yapılandırılmış sorular yöneltilerek konu hakkında detaylı bilgi edinilmeye çalışılmıştır. Araştırma soruları için Fatma Betül Karabıyık tarafından 2015 yılında yayınlanan “Türk Bankacılık Sektöründe İnsan Kaynakları Yaklaşımı Çerçevesinde Yetenek Yönetimi” adlı yüksek lisans tezinden yararlanılmıştır. Yüzyüze yapılan görüşmelerde en kısa görüşme 20 dakika, en uzun görüşme ise bir saat sürmüştür.

Görüşmeler sonrası elde edilen bulgular ışığında bankalar tarafından uygulanan yetenek yönetimi uygulamaları karşılaştırılmış ve ortak yönler ortaya konulmuştur.

İnsan kaynakları yetenek yönetim birimlerindeki uzmanlara aşağıdaki soruları cevaplamaları istenmiştir.

1. Bankacılık sektöründe yetenekli çalışanın işe alım şekli ve süreci nasıldır?

2. Bankacılık sektöründe yetenekli çalışanın performans ölçümü nasıl yapılır? Hangi stratejileri uygulanır?

3. Bankacılık sektöründe yetenekli çalışanlarıbünyenizde tutmak için yöntemleriniz nelerdir? 
Göktaş, P., Çetinceli, P. (2017). A research on talent management in terms of human resources management in the banking sector. International Journal of Social Sciences and Education Research, 3(3), 720-733.

4. Bankacılık sektöründe yetenekli çalışanın kariyer planlaması nasıl yapılır?

5. Bankacılık sektöründe yetenekli çalışanına uygulanan ücret politikaları nasıldır?

6. Bankacılık sektöründe yetenekli çalışanına verilen sosyal haklar nelerdir?

7. Bankacılık sektöründe yetenekli çalışanına verilen sorumluluklar nelerdir?

8. Bankacılık sektöründe yetenekli çalışanına sunulan eğitim olanakları nelerdir?

\subsection{Işe alım şekli ve sürecinde yetenek yönetimi yaklaşımı}

A Bankası'nda işe alım süreçleri kapsamında kullanılan araç ve yöntemler arasında; kişinin beklenen bilişsel düzeyinin gerçeğe en yakın şekilde ölçülebilmesini sağlayacak, normları belirlenmiş genel yetenek testleri, teknik (bankacılık) konu bilgisinin yeterli düzeyde olduğunu sınamak amacıyla uygulanan teknik konu sınavları, işle doğrudan ilintili ve gözlemlenebilir veri üretilebilmesini sağlayan değerlendirme merkezi ve yetkinlik bazlı mülakat uygulamaları ve çeşitli kişilik testleri bulunmaktadır. Yazılı sınavda başarılı olan adayları bölge ihtiyaçları doğrultusunda mülakata alınmakta bireysel ve grup mülakatlarında başarılı olan adaylarda kariyer eğitimlerine davet edilmektedirlerdir. Bu uygulamalar adaylar için objektif, adil, açık ve standart bir alım süreci gerçekleştirilmesini sağlamaktadır.

B Bankası'nda işe alım koşulları belirlenmekte, deneyimli veya sınavla personel alımı olmaktadır. İnsanı merkeze alan insan kaynakları politikalarının hedefi bu doğrultuda çalışanlarının geleceğe güvenle bakmasını sağlamaktır.

C Bankası'nda işe alım sınavlarının ne şekilde yapılacağı ve duyurulacă̆ 1 ile nerede yapılacağına Genel Müdürlük tarafından karar verilmektedir. Özel seçme sınavıyla (Müfettiş Yardımcısı, Kontrolör Yardımcısı ve Uzman Yardımcısı) alınacak memurlar, ilgili yönetmeliklerinde belirtilen esaslar içerisinde sınava tabi tutulmaktadırlar. İşe alınacak personel mülakat sınavına tabi tutulmaktadır. Genel Müdür tarafından mülakat komisyonunun ve/veya mülakatçıların kimlerden oluşacağı belirlenmektedir. Mülakat komisyonu/mülakatçı kanaatlerini bir tutanakla belirlemektedir. Kurumsal bir çalışma düzenine sahip olan C Bankası'nda işe alım politikası personel ihtiyacının tespiti ile başlamaktadır. Bankada işe alınacak bireylerin; Personel Yönetmeliği gereğince en az 4 yıllık eğitim veren üniversitelerin, banka tarafından belirlenen ve Bankacılıkla ilgili olan bölümlerinden mezun olmaları (Örneğin; İktisadi ve İdari Bilimler Fakültelerinin ilgili bölümleri, Fen Edebiyat Fakültelerinin Matematik, İstatistik Bölümleri, Mühendislik Fakültelerinin Endüstri Mühendisliği Bölümleri gibi), ilana başvuruda bulunmaları, yapılacak sınava ve mülakata katılmaları gerekmektedir. Bankacılık faaliyetlerine destek veren birim alanlarına personel alımı ise ilgili birimin personel talep etmesiyle başlamakta, ihtiyaç ile ilgili olarak ilana çıkılmakta, ilana başvuran adaylar arasında uygun olan adaylara ulaşılarak sınava ve mülakata davet edilerek süreç devam etmektedir. Daha sonra uygun adaylar uzmanlık alanlarına yönelik hazırlanan sınava tabi tutularak mülakata davet edilmektedir. İşe alım süreci uygun adayların en kısa sürede göreve başlaması ile neticelendirilmektedir.

Üç bankanın işe alım şekli ve sürecindeki ortak noktalar irdelendiğinde, tüm bankaların genel müdürlük ve şube çalışanı olarak ayrım yaptığı görülmektedir. Genel müdürlük çalışanlarından strateji ve yönetsel becerilere hakim olması beklenirken, şube çalışanlarından ise kar odaklı satış 
Göktaş, P., Çetinceli, K. (2017). Bankacılık sektöründe insan kaynakları yönetimi açısından yetenek yönetimi üzerine bir araştırma. International Journal of Social Sciences and Education Research, 3(2), 720-733.

becerilerini ön plana koymaları beklenmektedir. Bu bağlamda bankaların insan kaynakları yönetimi birimi doğru elemanı doğru zamanda doğru yerde çalıştırmayı hedeflemekte olup işini en iyi yapan kişiyi en yetenekli olarak değerlendirmektedir.

\subsection{Performans değerlendirmesi kapsamında yetenek yönetimi}

A Bankası'nda Çalışan Performans Yönetimi Birimi, kurum içinde müş̧eri odaklı, yenilikçi bir hizmet anlayışının tüm çalışanlar tarafından benimsenmesini sağlayan bölümdür. Çalışan Performans Yönetimi Birimin yönettiği sistemde yıl sonunda çalışanla yöneticisi bir araya gelerek çalışanın ilgili döneme ilişkin performansı, hedef gerçekleşme durumu ve eğitim ihtiyaçları hakkında bir değerlendirme yapılarak değerlendirme sonuçları sisteme yansıtılmaktadır. Performans değerlendirme sonuçları doğrultusunda çalışanların eğitim ihtiyaçları tespit edilmekte ve gerekli programlara alınmaları sağlanmaktadır. Performans Yönetimi Sistemi de bankadaki diğer insan kaynakları süreçleri gibi bilgisayar yazılımı üzerinden yürütülmektedir. Yükselme sınavlarında burada belirlenen kriterler dikkate alınmaktadir.

B Bankası'nda görev pozisyonu için yetkinlik bazlı performans ölçümü yapılmaktadır.

C Bankası'nda altı ayda bir olmak üzere yılda 2 defa çalışanlarla performans görüşmeleri yapılmaktadır. Yapılan performans görüşmelerinde o dönemki hedeflerinin ne kadarını gerçekleştirdiği ne kadarının ise gerçekleştirilmemiş olduğu tespit edilmekte ve bir sonraki altı aylık dönem için hedefler belirlenmektedir.

Üç bankada da ortak olarak performans değerlendirilmesinde önceden belirlenen hedeflere ne kadar ulaşılıp ulaşılmadığı belirlenmektedir. Bu görüşmeler neticesinde genel puanlama yapılmakta ve ileride terfi ve performans ücretlendirmede kullanılmaktadır. Çalışan performans değerlendirmesiyle ilgili itiraz hakkına sahiptir. Performans değerlendirilmesine göre hedefe ulaşılamadıysa bunların neden kaynaklanabileceği araştırılmaktadır. Dolayısıyla performansın geliştirilmesine yönelik neler yapılabileceği belirlenmekte ve bir sonraki dönem için yeni hedefler oluşturulmaktadır.

\subsection{Kariyer planlaması sürecinde yetenek yönetimi}

A Bankası tarafından görevlerine yeni başlayan çalışanlar için işe uyum programı çerçevesinde "Kariyerime Başlarken Programı" düzenlenmektedir. Bu program kapsamında sınıf eğitimlerinin yanı sıra uzaktan eğitim uygulamaları, şube stajı, eğitim sonrası danışman desteği gibi farklı etkinlikler de yer almaktadır. Bankadaki kariyerleri süresince çalışanlar görev tanımlarının gerektirdiği özelleştirilmiş eğitim programlarına katılmaktadırlar. Kariyer haritaları doğrultusunda düzenlenen bu eğitimler dışında, tüm çalışanlar yıl içinde açık olan eğitim kataloğundan kendi gelişim ihtiyaçları doğrultusunda "Teknik Bankacılık" ve "Yetkinlik ve Beceri Geliştirme" konularında eğitim tercih edebilme imkanına sahiplerdir. Çalışanların sektördeki gelişmeleri yerinde izlemeleri ve uluslararası bankacılık deneyimi kazanmaları amacıyla yurt içindeki ve yurt dışındaki kuruluşlarda eğitimlere katılma ve muhabir bankalarda staj yapma imkanları da sunulmaktadır. İşe giriş pozisyonlarından bazıları şunlardır: Müfettiş yardımcısı, uzman yardımcısı, bilgi işlem yazılım uzmanı, memur, çağrı merkezi elemanı, operasyon elemanı, takip memuru, özel güvenlik görevlisi, şoför. 
Göktaş, P., Çetinceli, P. (2017). A research on talent management in terms of human resources management in the banking sector. International Journal of Social Sciences and Education Research, 3(3), 720-733.

B Bankası çalışanlarına kariyer hedeflerine ulaşabilmeleri için performans ve yetkinliklerinin yanısıra, bulundukları ünvan gruplarına gore yükselme sınavlarına katılım ve eğitim olanakları sunmaktadır.

C Bankası'nda kariyer planlaması, çalışanın bir üst unvana yükseltilmesi; öğrenim durumuna göre unvanda bekleme süresinin dolması, zorunlu eğitimlere katılması, sınavlarda başarılı olması, sicil değerlendirmesi sonucunun olumlu olması ve boş kadro olması koşullarının gerçekleşmesi halinde yapılmaktadır. Çalışanın bir üst unvana yükseltilebilmesi için unvanda bekleme süresini doldurması gerekmektedir. Bekleme süresini dolduran ve son unvanını aldığ 1 tarihten itibaren (en fazla son dört yılı kapsayan) hakkında düzenlenmiş olan müfettiş tezkiye notunun \%30'u ve idari tezkiye notunun $\% 70$ 'i alınarak hesaplanan nihai tezkiye ortalamas 50 ve üzerinde olan memur, yetkili yardımcısı, yetkili ve üst yetkili unvanlı personel, yükselme sınavına çağrılmaktadır. Tezkiye değerlendirmeleri dışında, esasları Genel Müdürlük tarafından tespit edilecek farklı değerlendirme kriterleri de söz konusu ortalamaya dahil edilebilmektedir. Genel Müdürlük tarafından yazılı sınav esasları belirlenmektedir. Özel seçme sınavıyla (Müfettiş, Kontrolör, Mali Analist ve Uzman) alınan memurlar, ilgili yönetmeliklerinde belirtilen esaslar çerçevesinde bir üst unvana yükseltilmektedirler. Müdür yardımcısı ve yönetici kontrolör unvanındaki çalışanın bir üst unvana yükselebilmeleri için yükselme eğitimlerine katılmaları, yazılı veya sözlü sınavda başarılı olmaları gerekmektedir. Sınavlara ilişkin tüm esaslar, sözlü sınav komisyonlarının oluşumu, yükselme eğitimi ve sınavlarının yapılış şekli, disiplinine ilişkin esaslar Genel Müdürlük tarafından belirlenmektedir. Bilişim Teknolojileri Görevlileri Grubu hariç olmak üzere diğer unvan gruplarındaki yükselmeler, en az bekleme süresi dikkate alınarak Genel Müdürlük tarafından belirlenen esaslar dahilinde yapılmaktadır. Müdür yardımcısı ve üstü unvanlar ile müfettiş yardımcısı, kontrolör yardımcısı, mali analist yardımcısı, uzman yardımcısı ve stajyer memur unvanları hariç olmak üzere tüm personelden idarenin ihtiyaç duyması halinde unvanda görev yaptıkları döneme ilişkin tezkiye değerlendirmeleri ile esasları Genel Müdürlük tarafından belirlenecek diğer değerlendirmelerin ortalaması "BAŞARILI" olanların unvanda bekleme süresi bir yıl, "ÇOK BAŞARILI" olanların ise iki yıl olarak kısaltılmaktadır.

Üç banka da kariyer planlaması yaparken performans değerlendirmelerini göz önünde tutmaktadır. Kariyer planlaması çalışanların fikirleri alınarak yapılmakta olup çok yüksek performanslı çalışanlar erken terfi ettirilebilmektedir. Şube çalışanı için kariyer hedefi; ticari/bireysel portföy yöneticisi, şef ve şube müdürü şeklinde ilerlerken; genel müdürlükte çalışanlar için çeşitli kademelerde yöneticilik imkanı bulunmaktadır.

\subsection{Yetenekli çalı̧̧anı elde tutmak için sunulan kariyer firsatları ve ücret politikaları}

A Bankası yetenekli yeteneksiz çalışan olarak bir sınıflandırma yapmamakta, her çalışanını potansiyel yetenek olarak görmektedir. Şube kadrolarında bulunan satış ve satış dışı kadrolara çalışanların yetenekleri ile orantılı olarak dağılım yapmaktadır. Çalışanlarına aylık ücretlerinin yanı sıra yılda 4 maaş tutarında ikramiye verilmekte ayrıca Genel Kurul tarafından bir önceki yıl performansı ölçüsünde belirlenen oranda yılda 1 kez kar payı ödemesi yapılmaktadır. Banka tarafından belirlenen sınavlarda başarı gösteren çalışanlara yabancı dil, kambiyocu ve mali tahlilci tazminatları ödenmektedir. Uzmanlık kadrosunda görevli mensuplara uzmanlık tazminatı, tam gün çalışan avukat, mimar, mühendis ve Bilgi Teknolojileri Bölümlerinde görev yapan çalışanlara görev tazminatı ödenmektedir. Müfettiş yardımcılarına yapılan ödemelerin yanı sıra ikamet adre- 
Göktaş, P., Çetinceli, K. (2017). Bankacılık sektöründe insan kaynakları yönetimi açısından yetenek yönetimi üzerine bir araştırma. International Journal of Social Sciences and Education Research, 3(2), 720-733.

sinde ya da ikamet adresi dışında bulunma durumlarına göre ayrıca gündelik verilmektedir. Yukarıda belirtilen ödemelere ek olarak; çalışanlara bulundukları görevin gerektirdiği Kasa Tazminatı, Ortak Servis Merkezi Tazminatı ve Çağrı Merkezi Tazminatı gibi tazminatlar ödenmektedir.

B Bankası tüm çalışanlarına yaygın yurt içi ve yurtdışı şube ağı aracılığıyla iş tatmini sağlayacak geniş kariyer imkanları sunmaktadır. Çalışanların yetkinliklerine uygun işlerde çalışması sağlanmaktadır. Çalışanlar, kendilerine sağlanan eğitimleri tamamlayarak kariyer hedeflerine yönelik bilgi ve becerilerini geliştirerek farklı görev pozisyonları arasında hareket imkanı bulmaktadır. Yöneticilerini de kendi bünyesinden yetiştirme yolunu seçmektedirler. Ücret politikası ünvan ve görev pozisyonu bazlı uygulanmaktadır.

C Bankası yetenekli çalışanını elde tutmak için takdirname ve para ödülleri sunmaktadır. Üst yöneticilerinin teklifiyle Genel müdür tarafından görevlerinde olağanüstü çaba ve başarı gösteren, örnek olacak şekilde müşterilere iyi davranan, arkadaşlarıyla iyi geçinmeyi ve ekip çalışmalarında istekli ve başarılı olmayı alışkanlık haline getiren, banka gelirlerini önemli ölçülerde artıracak veya masraflarda önemli tasarruflar sağlayacak yeni önerilerde bulunan, tahsili tehlikeye düşen banka alacaklarını olağanüstü gayret ve çalışmalarıyla tahsil ederek bankayı zarardan kurtaran, yangın, deprem, sel ve benzeri olayların meydana gelmesi halinde banka çıkarlarını üstün çaba ve fedakârlıklarıyla koruyarak kesin bir zarar ve ziyanı önleyen çalışana takdirname verilmektedir. Ayrıca, çalışanların başarı ve çabaları ölçüsünde Genel Müdür tarafından 1 maaş tutarında ödül, Yönetim Kurulu tarafından ise 2 maaş tutarında ödül verilmektedir. Bunların yanısıra sürekli çalışmayı özendirici ödüller yani kıdem tazminatının hesaplanmasına esas süre dikkate alınarak, Bankanın kuruluş günü itibariyle; 15 hizmet yılını tamamlamış bulunan çalışana Banka amblemli altın, 20 hizmet yılını tamamlamış bulunan çalışana kol saati verilmektedir.

Her üç banka da çalışanlarını yetenek çerçevesinde değil de performansa bağlı olarak ücret politikası belirlemiştir.

\subsection{Sosyal haklar ve sorumluluklar çerçevesinde yetenek yönetimi}

A Bankası çalışanlarının sosyal güvenlikleri, Banka Mensupları Emekli Sandığı Vakfı ve Munzam Sosyal Güvenlik ve Yardımlaşma Sandığı Vakfı tarafından sağlanmaktadır. Banka Mensupları Munzam Sosyal Güvenlik ve Yardımlaşma Sandığı Vakfı tarafından çalışanlara ilave emekli ikramiyesi ve ikinci bir maaş alma olanağı da sunulmaktadır. Ayrıca çalışanlara sağlık yardımı, öğle yemeği, servis, çocuk zammı, evlilik, doğum ve doğal afet yardımı yapılmaktadır. Sorumluluklar çerçevesinde müşterileri çalışma odağına alan sürekli öğrenmeye açık ve yenilikçi olarak verilen yetkileri kullanmak esastır.

B Bankası'nda emekli ve yardım sandığı kapsamında Sağlık hizmetleri ayrıca çalışanlara ulaşım desteği ve yetenek ücreti verilmektedir.

C Bankası Bankanın Kuruluş Kanunu ve Ana Sözleşmesine göre ödenecek temettüye ilave olarak, Genel Müdür, Genel Müdür Yardımcısı, Başkan ve Müdür unvanları ile bunlara denk diğer unvanlarda çalışanlar yılda bir kez jestiyon ikramiyesi (teşvik primi) ve tüm Banka çalışanına performans değerlendirme dönemleri itibariyle, performans yönetimi esasları çerçevesinde genel verimlilik primi (performans primi) ile bazı ürünleri, hizmetleri ve karlılığı teşvik etmek için benzeri primler ödeyebilmektedir. Yönetim Kurulu tarafından, ödemenin kişi ve miktar yönünden kapsamı, dağıtım ve diğer uygulama esasları belirlenmektedir. Banka personeline tespit edilen esas ve miktarlarda makam tazminatı, sorumluluk ve verimlilik tazminatı, kasa tazminat1, 
Göktaş, P., Çetinceli, P. (2017). A research on talent management in terms of human resources management in the banking sector. International Journal of Social Sciences and Education Research, 3(3), 720-733.

yabancı dil tazminatı, özel uzmanlık tazminatı, bilgisayar tazminatı, meslek tazminatı, zırhlı araç tazminatı ödenmektedir. Bununla beraber giyim yardımı, ölüm ve malullük yardımı, afet yardımı, mesken yardımı, yemek yardımı, evlenme yardımı, doğum yardımı yapılmakta, ücret zammı ve Toplu İş Sözleşmeleri ile belirlenen diğer tazminat, yardım ve parasal haklar sunulmaktadır. Sorumluluklar çerçevesinde verimli ve karlı çalışmayı sağlamak kendisine verilen yetki ve mevzuat kapsamında işlemleri yürütmek esastır.

Sosyal haklar çerçevesinde üç banka da yetenekli çalışanlar ile diğer çalışanlar arasında keskin bir çizgi çizmemektedir.

\subsection{Eğitim faaliyetleri açısından yetenek yönetimi}

A Bankası'nın eğitim faaliyetleri açısından Kariyere Başlarken Eğitimi, Eğitim Danışmanları, İşe Merhaba Web Sitesi, E-Öğrenme, Takım Arkadaşı Uygulaması, Şube Müdürleri Gelişim Programı bulunmaktadır. Böylece çalışanlar şube denetim ve yönetimi hakkında bilgi sahibi olmakta, kredi tahsis ve takibi yürütmekte, yasal değişiklikler hakkında bilgi sahibi olmakta ve seçimlik modül sayesinde eksik görülen alanları tamamlayabilmektedir.

B Bankası'nın eğitim ve gelişim yönetimi anlayışının temelini, yönetici ve liderlerini kendi içinden yetiştirme geleneği doğrultusunda sürekli gelişim ve insana yatırım oluşturmaktadır. Çalışanların iş hayatlarında daha yüksek standartlara ulaşmalarını sağlayan sınıf içi, işbaşı ve uzaktan mesleki ve kişisel gelişim eğitimleri Ankara ve İstanbul merkezlerine ek olarak Türkiye genelinde 24 farklı lokasyonda sunulmaktadır. Yetenek yönetimi programları aracılığıyla çalışanlar inovasyon, yaratıcı düşünme, girişimcilik ve vizyoner liderlik yetkinliklerini geliştirme imkanı bulmaktadırlar.

C Bankası, banka kadrosuna yeni ataması yapılan ve mevcut personelin bilgi ve uzmanlığını artırmak, yönetici ve yetenekli eleman yetiştirmek amaciyla kurslar ve seminerler düzenlemekte veya diğer kurumların açacağı kurs ve seminerlere personelin katılmasını sağlamaktadır. Bankanın talebi doğrultusunda personel bu kurs ve seminerlere katılmak zorundadır. Terfi, nakil gibi konularda personel değerlendirilmesinde bu kurs ve seminerlerden almış olduğu not ve bankac1lıkla ilgili ihtisas konularında yüksek lisans eğitimi dikkate alınmaktadır. Genl Müdürlük tarafından bir yönetmelikle belirlenmektedir.

Her üç banka da eğitimin sürekliliği ilkesini benimsemiş olup eğitim ihtiyaçlarını performans değerlemesine göre tespit etmektedir.

\section{Sonuc}

Yetenek yönetimi uygulamalarının, bankacılık sektöründe faaliyet gösteren finans kuruluşlarının varlığını sürdürebilmesindeki en önemli faktörlerden olan insan kaynağı üzerindeki etkisini ortaya koymak amacıyla gerçekleştirilen bu çalışmada Türk bankacılık sektöründe lider konumunda olan 3 bankanın insan kaynakları yetenek yönetim birimlerindeki uzmanlar ile görüşme yöntemi aracılı̆̆ıyla yetenek yönetimi konusundaki uygulamaları incelenmiştir. Araştırma yöntemi olarak nitel araştırma tekniği tercih edilmiş olup insan kaynakları yetenek yönetim birimlerindeki uzmanlara yapılandırılmış sorular yöneltilerek konu hakkında veriler toplanmıştır.

Araştırmadan elde edilen bulgular ışı̆̆ında yetenek yönetimi işe alım şekli ve sürecinde, performans değerlendirmesi kapsamında, kariyer planlaması sürecinde, kariyer firsatları ve ücret po- 
Göktaş, P., Çetinceli, K. (2017). Bankacılık sektöründe insan kaynakları yönetimi açısından yetenek yönetimi üzerine bir araştırma. International Journal of Social Sciences and Education Research, 3(2), 720-733.

litikasında, sosyal haklar ve sorumluluklar çerçevesinde, eğitim faaliyetleri kapsamında ele alınmıştır. Dolayısıyla Türk bankacılık sektöründe lider konumunda olan 3 bankanın yetenek yönetimi uygulamalarına yer verilmiş olup, ortak yönlerine değinilmiştir. Bu bağlamda araştırmanın örneklemini oluşturan üç bankanın ortak uygulamalarına değinmek gerekirse; her üç banka da işe alım şekli ve sürecinde genel müdürlük ve şube çalışanı olarak ayrım yapmakta olup, Genel müdürlük çalışanlarından strateji ve yönetsel becerilere hakim olması beklenirken, şube çalışanlarından ise kar odaklı satış becerilerini ön plana koymaları beklenmektedir. Dolayısıyla doğru elemanı doğru zamanda doğru yerde çalıştırmak esastır. Performans değerlendirme ile hedeflerin gerçekleşip gerçekleşmediği belirlenmekte, gerçekleşmediyse bunların nedeni tespit edilmeye çalışılmaktadır. Gerek kariyer planlaması sürecinde, gerek terfilerde gerekse de ücret politikalarının belirlenmesinde performans değerlemesi baz alınmaktadır. Sosyal haklar çerçevesinde üç banka da yetenekli çalışanlar ile diğer çalışanlar arasında keskin bir çizgi çizmemektedir. Eğitim faaliyetleri kapsamında ise eğitimin sürekliliği ilkesi benimsenmiş olup eğitim ihtiyaçlarını performans değerlemesine göre tespit etmektedirler. Dolayısıyla insan kaynakları fonksiyonlarının yetenek yönetimi uygulamalarıyla entegre olarak yürütülmesi gerekmektedir.

\section{Kaynakça}

Alayoğlu, N. (2010), İnsan Kaynakları Yönetiminde Yeni Dönem, Ticaret Ve Turizm Eğitim Fakültesi Dergisi, (1).68-97.

Aldemir, C., Ataol, A. ve Budak, G. (2004). Insan Kaynakları Yönetimi, İzmir, Barış Yayınları, Fakülteler Kitabevi, (B.5).

Aston, C., ve Morton, L. (2005), Managing Talent For Competitive Advantage, Strategic Hr Review 4(5), $28-31$.

Atl1, D.,(2012). Yetenek Yönetimi.1.Bask1. İstanbul Crea Yayınc1lık

Beer, M., Cannon, M.D. (2004). Promise And Peril İn İmplementing Pay-Forperformance. Human Resource Management, 43(1), 3-48.

Berger, L.A. ve Berger, D. R. (2004). The Talent Management Handbook, Newyork, The Mcgraw-Hill Companies.

Bingöl, D. (2013). İnsan Kaynakları Yönetimi, 8. Baskı, İstanbul: Seçkin Yayıncılık

Creelman, D, (2004), "Return On Investment In Talent Management: Measures You Can Put To Work Right Now”, Human Capital Institute , 2121 K Street, N.W., Suite 800, Washington, Dc 20037 Usa.

Çırpan, H. ve Şen, A.,(2009) “İşletmelerde Yenilikçiliğgi Geliştirmede Etkili Bir Araç: Yetenek Yönetimi”, Çerçeve Dergisi , MÜSİAD, 110-116.

Doğan, S. ve Demiral, Ö. (2008). İnsan Kaynakları Yönetiminde Çalışanların Kendilerine Doğru Yolculuk Yöntemi: Yetenek Yönetimi, C.. Ü. Sosyal Bilimler Enstitüsü Dergisi, 17(3), 145-166.

Erdoğan, İ. (1999). İşletmelerde Kişi Değerlemede Psikoteknik, 5.Bs., İstanbul,İ.Ü İşletme Fakültesi.

Karabıyık, F B. (2015). “Türk Bankacılık Sektöründe İnsan Kaynakları Yaklaşımı Çerçevesinde Yetenek Yönetimi” Muğla Sitkı Koçman Üniversitesi Sosyal Bilimler Enstitüsü İşletme Ana Bilim Dalı, Muğla.

Keçecioğlu, T., (2012). İnsan Kaynakları Yönetimi Yoluyla Rekabetçi Avantaj Kazanmak. 1.Baskı. İstanbul: Hümanist Yayıncılık

Levis, R. E. ve Heckman, R. J. (2006). Talent Management: A Critical Review, Human Resource Management Review (16), 139-154. 
Göktaş, P., Çetinceli, P. (2017). A research on talent management in terms of human resources management in the banking sector. International Journal of Social Sciences and Education Research, 3(3), 720-733.

Mccauley, C.; Wakefield, M. (2006), “Talent Management In The 21st Century: Help Your Company Find, Develop And Keep Its Strongest Workers”, The Journal For Quality \& Participation, Winter, 29(4), 4-7.

Mucha, T. R. (2004), “The Art And Science Of Talent Management”, Organization Development Journal, Winter, 22 (4), 96-100.

Muradova, Terane (2007), İnsan Kaynakları YöNetiminde EğItim Ve GelişTirmenin ÖNemi, Khazar Journal Of Azerbaijani Studies, 10(3-4), 75-84.

Purcell, J. (2001). The Meaning Of Strategy in Human Resource Management. J. Storey (Der.) İçinde, Human Resource Management: A Critical Text (S. 59-76).London: Thomson Learning.

Sabuncuoğlu, Z. Ve Tokol, T. (2013). İşletme, İstanbul: Beta Basım A.Ş

Selznick, P. (1984). Leadership In Administration, University Of California Press, Berkeley.

Tabancalı, E. ve Korumaz, M. (2014). Eğitim Örgütlerinde Yetenek Yönetimi, The Journal Of Academic Social Science Studies International Journal Of Social Science Number: 25-I, 139-156.

Timur, N. (2006) Banka ve Sigorta Pazarlaması, Anadolu Üniversitesi Yayını, No: 1701. Eskişehir.

Uyargil, C. vd (2010). Insan Kaynakları Yönetimi. (5. Basım). İstanbul: Beta Yayınları.

Uysal, Ş. (2015) Performans Yönetimi Sisteminin Tanımı, Tarihçesi, Amaç Ve Temel Unsurlarına Genel Bir Bakış, Electronic Journal Of Vocational Colleges, 32-39. 
Göktaş, P., Çetinceli, K. (2017). Bankacılık sektöründe insan kaynakları yönetimi açısından yetenek yönetimi üzerine bir araştırma. International Journal of Social Sciences and Education Research, 3(2), 720-733.

\section{Extended abstract in English}

All around the World, economic and structural transformation process progressing rapidly has been brought globalization and competition. Today, increased international competition and technological developments with the impact of globalization brings about the necessity of change in terms of businesses. As a result of along with the globalism, disappear of the borders, technologic developments and unavoidable passing to the information society, has been deeply affected and changed the current rules of the business world. So that the importance of competitive power and superiority has been come into prominence and the organizations' understanding of competition has been changed significantly. In other words, the renovation of information and technology and new opportunities in economic life, have been caused changes in the quality of human resources, which will contribute to the process of universal values. One of area where change is most felt is human resource management. 20th century has been era that, to sustain the competitive advantage of enterprises, having inimitable sources, in other words having talented manpower, retaining them and handling towards the rights of enterprises is of critical importance. For this reason, talented manpower is decisive for the success of enterprises in today's conditions of competition. The need for high potential and skilled workers is increasing to meet the requirements of the era of the business.

One of the new concepts resulting from these needs is "Talent Management". One of the success factors of human resources departments of the most enterprises in recent years that talent management concept has been created a new vision trend among the business strategies in terms of organization, continuation and management of global labour force. In other words, the concept of talent management is encountered as a new vision between business strategies to incorporate global workforce of the organization, to protect in the current situation of workforce and to management. The organizations which have been working in an environment that has been getting more and more difficult to attract and retain talented employees to the organization, should be benefit from talents that they have effectively toward with the organization's objects with talent management strategies. In this context, one of the service-intensive industry which aims to bring together the most talented employees is the banking sector. The banking sector by investing in human resources to achieve this target and is expected to reach maximum profitability and efficiency as a result of it. In addition, with talent management for the employees it should be made possible to improve themselves and so that this increase makes them willing to stay in the organization. And increases organizational commitment of them.

The power components of a highly effective talent management process include:

- The organization's current and future business strategies should be clear understood.

- The key gaps between the talent in place and the talent should be identificated for required to drive business success.

- A plan of talent management can be designed for getting closer the talent gaps. This talent management plan should also be integrated with strategic and business plans.

- Hiring and promotion decisions should be accurate.

- To corporate goals, and providing clear expectations and feedback to manage performance, individual and team goals should be connected. 
Göktaş, P., Çetinceli, P. (2017). A research on talent management in terms of human resources management in the banking sector. International Journal of Social Sciences and Education Research, 3(3), 720-733.

- To enhance performance in current positions as well as readiness for transition to the next level, talent should be developed.

- A focus not just on the talent strategy itself, but the elements required for successful execution.

- During and after implementation business impact and workforce effectiveness measurement.

In this study, the concept of 'Talent Management' which is a new vision in 'Human Resources Management' going to be analysed. This study aims to reveal the impact on human resources of talent management practices and also the research is to make a determination on the status of the banks operating in the Turkish Banking System in relation to human resources management practices. In this direction, three banks that pioneers in human resources with modern practices in Turkey, adopted the talent management perspective and made it one of the strategic priorities, banks have been analysed. In this context, data were collected through interviews with human resources experts in talent management unit who working in 3 bank that leading position in Turkish banking sector. Opinions about the talent management in the Turkish banking sector has been determined by evaluating data. The findings obtained from this study showed that effective talent management practices have a significant impact on the human resources who have critical importance to maintain existence of financial institutions that operating in the banking sector. Besides it has been concluded that the bank's human resources and talent management practices have been positively affecting the operations of the bank. 